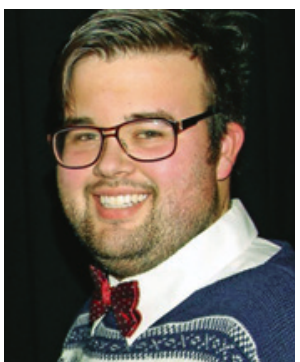

\title{
Overvekt og fordommer
}

\section{Jeg ser på meg selv som en relativt} ålreit person - litt selvsentrert, til tider distré, over middels engasjert, født med litt for mye energi, høy latter og generelt godt humør. A ja, jeg er forresten ganske så feit også!

Den sto der, midt i rommet. Fulgte meg med blikket. Ei vektskive til munn, med en geip som pekte farlig langt mot høyre. Det er mitt første minne fra norsk helsevesen. Det andre jeg husker er en lang, slank mann i hvit legefrakk som lente seg over meg og opplyste om at jeg hadde gått opp en hel smørpakke. Igjen.

Det var i midten av 1990-årene på et typisk norsk legekontor. I dag, på den andre siden av millenniet, får jeg som leder i Landsforeningen for overvektige høre ekkoet av mine egne minner i medlemmenes historier fra de samme legekontorene i 2014. Det er historier fra mennesker som har dype arr etter møter med norsk helsevesen gjennom mange år. Dette fordi overvekt i altfor mange år er blitt sett på som et moralsk problem, ikke som et medisinsk.

I dag, i et hvilket som helst kommentarfelt i en hvilken som helst norsk nettavis som åpner for kommentarer for leserne: «De kan skylde seg sjæl. Det er bare å spise mindre og trene mer, så blir man ikke tjukk. Feite svin!» I større grad enn noen gang tidligere blir overvektige diskriminert i samfunnet, latterliggjort og sett på som et lass av fett.

Men dessverre er det ikke bare fra nettrollene beskjeden kommer. For til så altfor mange overvektige kommer den samme beskjeden fra helsevesenet også, dog uten «feite svin!» til slutt. I alle fall ikke direkte uttalt. En slik beskjed oppleves som den rene avvisning når man omsider har våget å oppsøke legen i håp om å få hjelp med et problem som bokstavelig talt er blitt for stort. For stort til at man kan hanskes med det på egen hånd. Jeg vil bort fra dagens situasjon der vellykkethet måles i antall rader vaskebrett på magen eller hvor lav fettprosent du har. Dette er urovekkende tendens som jeg mener samfunnet må ta på alvor, helt uavhengig av fedmedebatten.

$\AA$ A erkjenne at man er sykelig overvektig og trenger hjelp tar lang tid. Jeg husker selv den dagen jeg sto på kontoret hos min fastlege og sa: «Nå trenger jeg hjelp, dette går ikke lenger! Jeg er redd for at jeg aldri blir 30 år.» Men før jeg kom dit var det en lang egenprosess. Mange sykelig overvek tige tør aldri oppsøke helsevesenet før det er for sent, rett og slett fordi tabuet og stigmaet ligger som en skygge over begrepet «overvekt». Tabuer snakkes det sjelden om. Det er nettopp dette som er min oppfordring til dere: Snakk om det! Vær tålmodig, vis respekt, ta deg tid, se meg, men ikke glem å snakke om det!

Og gå deg ikke bort i dine egne fordommer ved å snakke om det faktum at pasienten er feit og hvor feit han eller hun er. Snakk om hvorfor det er blitt slik. Hvorfor stoppet man ikke da vektnåla begynte å bevre faretruende langt mot høyre? Hva er det som gjorde og gjør at man ikke «bare spiser mindre og trener mer»? Vi er feite i kroppen, ikke tjukke i huet. Så må heller ikke vi gå oss bort i våre fordommer og tenke at dere er leger fordi dere var så himla flinke på skolen og født med en syk trang til diagnostisering. Kanskje er du lege på tross av at du i utgangspunktet ikke var så flink, men du overvant det fordi du hadde et brennende ønske om å hjelpe mennesker? Kanskje vi begge må se hverandre i et nytt lys?

Og får du en overvektig pasient - forbered deg! Plutselig er dagen der da vedkommende er klar for å ta grep. Da er det godt å komme til en lege som vet hvilke behandlingsmuligheter som finnes. Som min lege, som da jeg kom til ham møtte meg med: «Dette skal vi klare sammen. Selvsagt skal du feire 30-årsdagen!» Men vær, som min lege, forberedt på dette: $\AA$ kurere sykelig overvekt er ikke som å behandle et brukket bein. Det er ikke slik for oss overvektige at man legges på et operasjonsbord eller sendes på rehabilitering i noen uker og vips, så er man erklært frisk. Vi trenger hjelp over lang tid.

Dere må gå denne veien sammen med oss. Og glem ikke å se meg mens vi går. Det er ikke et nytt og bedre menneske som kommer frem etter hvert som kiloene forsvinner. Jeg har vært der hele tiden, jeg. Men skal vi lykkes i kampen, så må fordommene forsvinne før fettet, ikke fordi fettet forsvinner! For da er vi like langt.

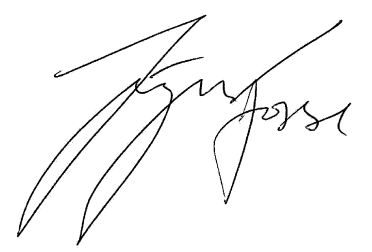

